\title{
Manual de Medicina Legal
}

\author{
E.S.S. Diniz ${ }^{a, *}$ \\ ${ }^{a}$ Universidade de Vassouras - Curso de Medicina-RJ, Brasil \\ * Endereço de e-mail para correspondência: sampaiodiniz@hotmail.com.Tel.: +55-24-99936-8721.
}

Recebido em 01/03/2020; Revisado em 05/05/2020; Aceito em 05/05/2020

\section{RESENHA}

O livro Manual de Medicina Legal trata-se de uma obra que contribui significativamente para a formação acadêmica do leitor. Voltado para estudantes de Direito, traz consigo uma linguagem bem simples e compreensível, explanando sobre os principais aspectos da medicina legal direcionados à prática criminalística cotidiana.

A obra foi elaborada por Delton Croce e Delton Croce Júnior, ambos advogados especialistas em perícias médico-legais e professores em instituições de ensino de superior.

O livro apresenta uma organização de tópicos que facilita o prosseguimento e assimilação de seu conteúdo e aborda temas relevantes no universo das perícias médico-legais. É composto por 17 capítulos que abordam os temas de forma objetiva e com grande aplicabilidade prática.

A introdução do livro se concentra nos conceitos fundamentais da medicina legal e discorre sobre temas como seu surgimento, histórico e relação com demais especialidades e profissões. Os capítulos subsequentes abordam temas sobre legislação pericial e medicina forense. Assuntos como antropologia, traumatologia, tanatologia, sexologia, psicologia e psicopatologia forenses são descritos com maestria. Claramente, temas como causas jurídicas da morte, infortunística acidentária e perícias médico-legais não ficariam de fora dessa esplêndida obra.

A maneira como os assuntos são abordados bem como a linguagem adotada permitem que profissionais de outras áreas e até mesmo leigos, interessados no assunto, façam bom proveito do livro. Com certeza uma obra que todos os amantes da medicina legal deveriam ler.

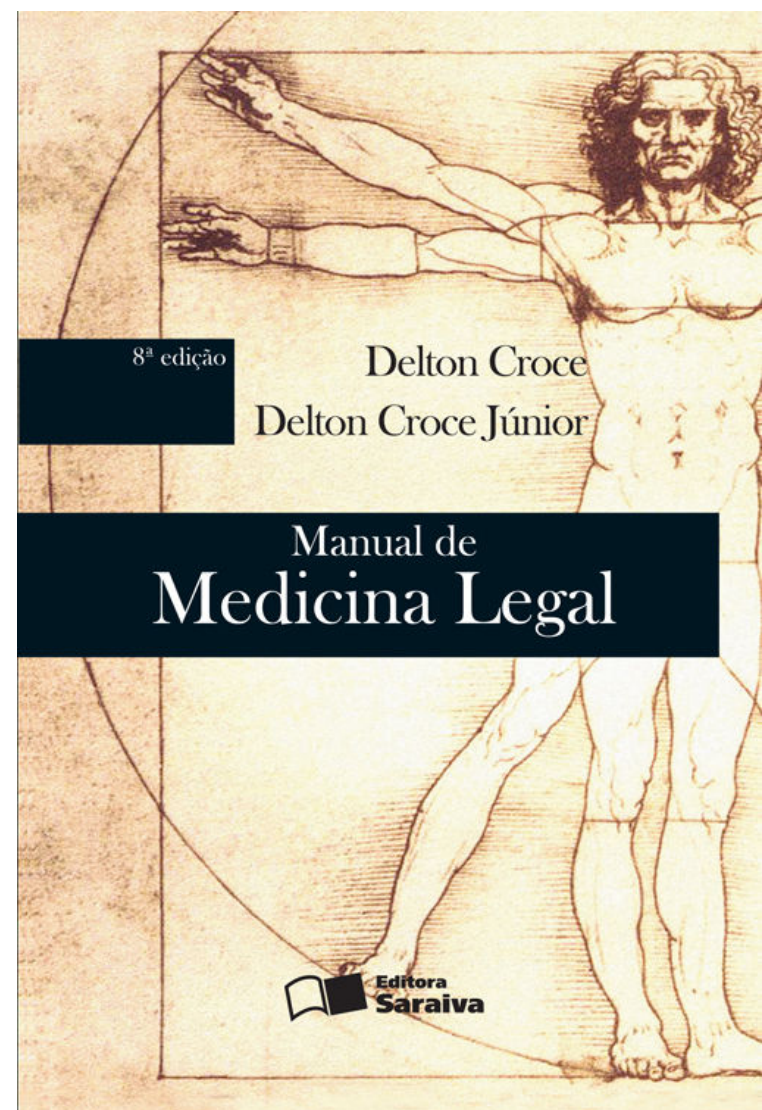

Manual de Medicina Legal / Delton Croce, Delton Croce Júnior. - 8. Ed. - São Paulo: Editora Saraiva, 2012.

Número de páginas: 872

Formato: $22,4 \mathrm{~cm}$ por $15 \mathrm{~cm}$

Capa comum

ISBN 978-85-0211-140-0 